\title{
FINE MOTOR SKILLS DEVELOPMENT IN PRESCHOOL-AGE CHILDREN WITH SPEECH AND LANGUAGE DISORDERS
}

\author{
Lūcija Anoško \\ University of Latvia, Latvia
}

\begin{abstract}
Children with speech and language disorders are characterized not only by the unique development of the speech but also by specific characteristics of cognitive and sensory motor skills. The research was based on the theoretical recognitions about the specific characteristics of child development in case of speech ontogenesis and dysontogenesis. In order to specify the development level of fine motor skills of the children, the same diagnostic activities were used that usually are used by the teachers-speech therapists in order to check the speech and language development of the children, as well as the cognitive and the motor abilities. In addition, the speech and language development of the children was checked.

Participants of the research were the pre-school age children with different speech and language disorders, ages 3 to 6 , totally 27 respondents; they go to the pre-school education institution for children with speech and language disorders. The children were divided into 2 groups: in the first group there were non-verbal children $(n=5)$ and in the second group there were verbal children with different speech and language disorders $(n=22)$. During the research, there was observation of the children and corrective developmental intervention. The results of the research show that there is strong correlation between the speech development and development of fine motor skills (fine muscles). The reduction of the speech and language disorders is tightly connected with the improvement of fine motor skills.
\end{abstract}

Keywords: preschoolers, fine motor skills, speech and language disorders.

\section{Introduction}

The development of a child starts at the moment of birth and continues to develop during the pre-school age. Well-developed fine motor skills play a big role in the intellectual and psychophysical development of a child. The famous educator Sukhomlynskij said that "the mind of a child is located at his fingertips" (Сухомлинский, (Suhomlinskij) 1986, 16).

The other famous phychophysiologist and movement physiologist Bernstein once said that "during the movement exercise it is not the hand 
that is trained but the brain" (Бернштейн, (Bernstein) 1990). Simultaneously with hand movements there is the sensory development of speech/language, the ability to express oneself freely. Unless the movements of every finger of hands become free and unrestricted, the correct development of the speech is restricted; if the fingers of hands are developed, the speech and thinking of a child will develop. Developed fine motor skills are a significant element of the psycho-physical, emotional and cognitive development of the child.

What are the fine motor skills? The fine motor skills are the ability of fingers to perform all the differentiated movements that determine a successful establishment of different self-service and learning, work and other operations (Cameron et al., 2012; Семенович, (Semenovich) 2002). The area of fine motor skills includes big number of different movements: from simple gestures (grasping of toys) to very complicated movements (like drawing and writing).

In the traditional ontogenetic understanding a child discovers the surrounding world through movements and words and through interaction with it (Семенович, (Semenovich) 2002). As a result of this interaction, the consciousness of the child is formed, and his personality grows and develops as well. In this process action and interaction play the most important role. Movement and speech are the most significant factors allowing the child to comprehend the world of objects, to develop the level of sensory and motoric understanding as the starting point of personality growth. This process takes a long time: at the moment of birth of the child the structure of the brains of the left and the right cerebral hemisphere is identical. When the functions of hands start to develop, the cerebral hemisphere of brain that is associated with it is developed more since the leading impulses get there (Семенович, (Semenovich) 2002). However, when the level of the fine motor skills development is low, the speech development of the child will also be impaired, although the gross motor skills might be within the standard limitations or even above the standard (Sibley \& Etnier, 2003).

The goal of the research is to analyze the mutual relations between the speech and language disorders and the development of fine motor skills.

The methods of the research: analysis of the scientific literature sources, investigation of the children in the context of speech therapy, observation and corrective developmental intervention, summarizing and analysis of the acquired data.

\section{Theoretical framework}

The development of fine motor skills is an important part of the corrective work performed with children with speech disorders. A pre-school child 
learns about the world around and gets to know it through the activities of hands (Šternfelde, 2017; Brooks, Kempe, 2014; Berninger et al., 2006). This age (from 3 until 6-7 years) is the most beneficial time to develop the intellectual, psycho-emotional and creative skills - it is the time when cerebral cortex of the big halves of brains has not yet fully matured. The child has a need for movements: move different objects, grab everything with hands, draw, write, get dressed, get shoes on, do other every-day and learning activities. All of those tasks require coordinated and precise movements of palms and fingers. The small muscles of fingers work together with the higher mental functions - memory, imagination, visual and movement memory, speech (Brooks, Kempe, 2014; Dinehart \& Manfra, 2013; Tūbele et al., 2013; Loras et al., 2013).

Many researchers confirm that exercising the fine movements of fingers stimulates the general and speech development of a child (Cameron et al., 2012; Kurtz, 2008; Berninger et al., 2006; Sibley \& Etnier, 2003; Семенович, (Semenovich) 2002; Бернштейн, (Bernstein) 1991; Кольцова, (Kolcova) 1973). The development of the psychomotor characteristics happens in all types of the motoric spectrum: gross motor skills, fine motor skills, articulation. The famous educator Montessori has based her pedagogical method on the idea about the possibility to stimulate the activity of brains using the exercises of hands; the more the hands of a child are involved in different kind of activities, the better other cognitive processes develop.

The fine motor skills develop naturally from the early age of the infant. In the pre-school age, they continue to develop and become more complicated (Turkington, Harris, 2006). For a 3 years old child there are following characteristics of fine motor skills of hands: holding the pencil in hands, drawing with pencils, building houses from 8-9 blocks, catching the ball with both hands; then at the age of 6 years the child can draw letters and numbers, the holding strength of the hands has developed, the child can cut out pictures using scissors.

The play methods for hand exercises of children are activities that are universally didactic and developing (Brice, 2007). The main idea of play methods is based on the knowledge that the ends of nerves in the tips of fingers influence the brain of a child, and brain activity is therefore activated. Finger games is a great tool preparing the hands of children for writing (Dinehart \& Manfra, 2013), therefore the level of development of fine motor skills is a crucial element in order to evaluate whether the child is ready for the school (Suggate et al., 2017; Bindman et al., 2014). In modern days there are high requirements regarding children who start learning in the school: they need to be well prepared. If the movements of fingers of a child have not developed sufficiently, there can be problems to learn to write, therefore it is so important to enhance the abilities of fine 
motor skills in the pre-school age so that the process of learning to write would be more successful.

\section{Methodology}

Research took place from September 2018 until January 2019 in the preschool educational institution of Riga for children with speech and language disorders. Participants of the research were twenty-seven children of different ages (from 3 until 6 years old) and with different speech and language disorders. At the beginning of the research five children are nonverbal (two girls and three boys), twenty-two children are verbal (five girls and seventeen boys) with speech disorders with different etiology.

Methods used for the research: exploring of the anamnesis of every child (at the beginning of the research in September); analysis of the fine motor skills and speech and language in the starting phases and at the end of the research; analysis of the interaction between finger development and speech development using the Pearson correlation coefficient.

\section{Results}

During this research, the focus is mainly on the development level of fine motor skills. The research was divided into 3 phases:

1. phase: Testing of the speech and language abilities and the development of the fine motor skills of the children.

2. phase: Corrective actions for the improvement of the speech and fine motor skills.

3. phase: A repeated investigation of the speech and fine motor skills of the children as well as summarization, comparison, and analysis of the survey results.

In the beginning of September ( 2 weeks) the investigation of the language and speech abilities was done as well as the testing of the fine motor skills individually and in small groups (2-3 children). Speech abilities were tested according to several criteria: (understanding of speech - impressive language; usage of speech - expressive language; connected speech; pronunciation/articulation; skills of the phonological perception, skills of analysis and synthesis; pronunciation of words with complicated syllable structure). All criteria have distinct indicators that provide understanding about the level of speech skills of the respondent and compliance with the standards of ontogenesis (see Table1). 
Table 1. Investigation of the language and speech abilities

\begin{tabular}{|c|c|c|c|c|}
\hline Criteria & \multicolumn{4}{|c|}{ Indicates/ years } \\
\hline \multirow{2}{*}{$\begin{array}{l}\text { Impressive } \\
\text { speech }\end{array}$} & 3 years & 4 years & \multicolumn{2}{|l|}{$5-6$ years } \\
\hline & $\begin{array}{l}\text { is able to show } \\
\text { pictures of } \\
\text { nouns, verbs } \\
\text { and adjectives } \\
\text { that are used } \\
\text { daily, can } \\
\text { execute 2-level } \\
\text { instructions, } \\
\text { understands } \\
3 \text { prefixes from } \\
4 \text { (in, above, } \\
\text { under, from }\end{array}$ & $\begin{array}{l}\text { executes 2-3-level } \\
\text { instructions, has good } \\
\text { orientation skills } \\
\text { around the room, } \\
\text { recognizes "next to, } \\
\text { behind, many, few, } \\
\text { one", is able to show } \\
\text { pictures: nouns, verbs } \\
\text { and adjectives, basic } \\
\text { colors; understands } \\
\text { the correlation } \\
\text { between cause and } \\
\text { consequences }\end{array}$ & \multicolumn{2}{|c|}{$\begin{array}{l}\text { executes complicated } \\
\text { instructions, is able to } \\
\text { distinguish between similar word } \\
\text { combinations }\end{array}$} \\
\hline \multirow{2}{*}{$\begin{array}{l}\text { Expressive } \\
\text { speech }\end{array}$} & 3 years & 4 years & \multicolumn{2}{|l|}{ 5-6 years } \\
\hline & $\begin{array}{l}\text { creates com- } \\
\text { plete sentences, } \\
\text { is able to say } \\
\text { nouns, verbs } \\
\text { and adjectives } \\
\text { used daily, can } \\
\text { say own name, } \\
\text { gender and age }\end{array}$ & $\begin{array}{l}\text { creates a sentence } \\
\text { from 5-7 words, } \\
\text { the speech is gram- } \\
\text { matically formed, can } \\
\text { name pictures: nouns, } \\
\text { verbs and adjectives, } \\
\text { basic colors; seasons } \\
\text { of year, parts of a day }\end{array}$ & \multicolumn{2}{|c|}{$\begin{array}{l}\text { tells about things depicted on } \\
\text { the picture: names the objects } \\
\text { in one word/creates sentences } \\
\text { from two words/uses longer } \\
\text { sentences; understands the } \\
\text { correlation between cause and } \\
\text { consequences, can name days } \\
\text { of the week, seasons of a year, } \\
\text { months in sequence }\end{array}$} \\
\hline \multirow[t]{2}{*}{ Pronunciation } & 3 years & 4 years & \multicolumn{2}{|l|}{ 5-6 years } \\
\hline & $\begin{array}{l}\text { replaces/ } \\
\text { doesn't } \\
\text { pronounce } \\
\text { some sounds }\end{array}$ & $\begin{array}{l}\text { replaces/doesn't } \\
\text { pronounce some } \\
\text { sounds }\end{array}$ & \multicolumn{2}{|c|}{ pronounces all sounds } \\
\hline \multirow{2}{*}{$\begin{array}{l}\text { Phonological } \\
\text { perception }\end{array}$} & 3 years & 4 years & 5 year & 6 year \\
\hline & $\begin{array}{l}\text { repeats at least } \\
\text { two-syllable } \\
\text { rows with } \\
\text { sounds of early } \\
\text { ontogenesis }\end{array}$ & $\begin{array}{l}\text { repeats two-syllable } \\
\text { rows with sounds of } \\
\text { early ontogenesis }\end{array}$ & $\begin{array}{l}\text { repeats three- } \\
\text { syllable rows } \\
\text { with sounds } \\
\text { of early } \\
\text { ontogenesis } \\
\text { and sibilants; } \\
\text { is able to } \\
\text { determine } \\
\text { the first sound } \\
\text { in the word }\end{array}$ & $\begin{array}{l}\text { repeats three- } \\
\text { syllable rows } \\
\text { with sounds of } \\
\text { early ontogenesis } \\
\text { and sibilants; is } \\
\text { able to determine } \\
\text { the first and the } \\
\text { last consonant in } \\
\text { the word; is able } \\
\text { to determine } \\
\text { the sequence } \\
\text { of sounds in } \\
\text { the word }\end{array}$ \\
\hline \multirow{2}{*}{$\begin{array}{l}\text { Pronunciation } \\
\text { of words with } \\
\text { complicated } \\
\text { syllable } \\
\text { structure }\end{array}$} & 3 years & 4 years & \multicolumn{2}{|l|}{ 5-6 years } \\
\hline & $\begin{array}{l}\text { words with } \\
\text { one and two } \\
\text { syllables }\end{array}$ & $\begin{array}{l}\text { words with two } \\
\text { syllables }\end{array}$ & \multicolumn{2}{|c|}{ words with three-five syllables } \\
\hline
\end{tabular}


Each task is evaluated on the scale from 1 to 3 where 1 point means that the child did not fulfil the task; 2 points mean that the child performed the task with the help or by repeating; 3 points mean that the child fulfilled the task.

This evaluation was done individually, taking into account the psychoemotional condition of every child at the moment of the evaluation. The duration of each session differed depending on the age of the child and how ready the child was for the cooperation (minimum 5-10 minutes, maximum 20 minutes). Another important criterion for the evaluation was the current level of speech and language abilities of the child. If the child was verbal, then all criteria of speech development were tested; if the child was non-verbal, the impressive speech of the child was tested.

The following criteria were established to evaluate the development level of the fine motor skills for each child (see Table 2).

Table 2. Fine motor skills development

\begin{tabular}{|l|l|}
\hline Criteria & Tests \\
\hline Kinetic/dynamic skills* & $\begin{array}{l}\text { Fingers position } \\
\text { Graphical skills } \\
\text { "First - edge - palm" (A. Luria) } \\
\text { Finger movements }\end{array}$ \\
\hline Reciprocal skills** & $\begin{array}{l}\text { Fingers "marching" } \\
\text { "First - edge - palm" (both hands) (Luria) }\end{array}$ \\
\hline
\end{tabular}

*kinetic abilities (can the child keep the specified posture);

*dynamic abilities (can the child switch from one activity to another activity);

**reciprocal abilities (ability of the child to perform activities with both hands).

In the practical sense, the task was performed in the following sequence:

- try-out evaluation movements that are not evaluated;

- afterwards the speech therapist shows exercises that the child has to repeat.

If the child is not able to fulfill the task, the movement is shown again, and the child tries to repeat it again. If this also does not help, the method of passive movements is used: the tester positions the hand and fingers of the child in the correct position and then the child repeats the movement again by copying the tester.

Every test is evaluated according to the scale from 1 to 3 where:

1 point - the child did not perform the task;

2 points - the task was performed with the help of the adult;

3 points - the child performed the task.

The kinetic and dynamic praxis include different tests, for example: 
The tester asks the child to show "a rabbit", "a rooster", "a goat". The rest of the fingers need to be pressed to the palm and held in this position for the time when it is counted to 10 .

The interpretation of test results. The child is able to manage the bending muscles if he is able to keep the specific posture without straightening the fingers. The child is not sufficiently able to manage the bending muscles or is not able to manage them at all if fingers straighten unwillingly.

The establishing of the level of the graphical skills of the dominant hand. The process of testing. A pencil is given to the child and it is observed how the child is holding the pencil. Then the child is offered to draw 2 lines according to a template (a vertical and a horizontal line). Then the child needs to fill in the given template with the color using the colored pencils or crayons.

The result of the test is determined by a correct line, correct body posture during the work, by the fact if the movements of hand are relaxed.

The switching of finger movements of the dominant hand "Fist - edge palm" (Лурия, (Luria) 1973)

The process of the test. The tester offers the child to repeat a series of nine movements after himself. The series consist of movements that are repeated three times: "Fist - edge - palm".

There might be a disturbance: switching from one type of movement to the next; sequence of the movements.

Interpretation of test results. Switching between movements is considered sufficient, if the instructions of the tester are performed without mistakes. The switching is considered insufficiently developed if the switching of hand movements is disturbed: when the character of child's movements does not correspond with the instructions given by the tester.

Test to evaluate the level of precision of execution of finger movements "Fingers greet each other". The tester offers the child to make circles with the thumb and index finger and then with other fingers in a sequence.

Interpreting of test results. The precision of finger movements is considered sufficient if the child switches between the fingers swiftly, not making mistakes in the switching sequence. The precision of finger movements is considered not sufficient when the child executes the movements incorrectly, movements are clumsy, child makes mistakes in the sequence of actions.

The reciprocal praxis is tested using the following tests:

The test of "marching" with the fingers on the table. The tester shows the task to the child: the index finger and the middle finger are "marching". Both hands do the action simultaneously.

The test "fist - edge - palm" (Лурия, (Luria) 1973). The test is performed with both hands simultaneously, repeating the series of nine movements. 
According to the results of the diagnostics that was done in September among the twenty-two verbal un five non-verbal children the conclusion could be made that the level of speech and language development was average for eighteen children, low for five children and very low for four children. This can be concluded from the initial evaluation when none of the children could obtain the maximum number of points. The best result among the non-verbal children is 21 points out of 42 available, that one child obtained, among the verbal children one child obtained 40 points, two children 38 points, four children 37 points. The majority of verbal children showed the average level of speech development.

Also, the fine motor skills tests showed that the results for the nonverbal children were lower compared to the verbal children with different speech disorders. For the children who are non-verbal in the beginning of September, when tests are performed, the dynamic and reciprocal praxis is very low. The kinetic abilities are also not sufficiently developed. Regarding the verbal children, the kinetic and dynamic skills are well developed, they struggle with the tasks for checking the reciprocal abilities.

In order to establish if there is a statistically significant correlation between the level of speech development and fine motor skills development, the Pearson correlation coefficient was used. There is an analysis of the results acquired in September, so it can be concluded that there is a strong correlation $(r=0.886)$ between the researched criteria (see Figure 1).

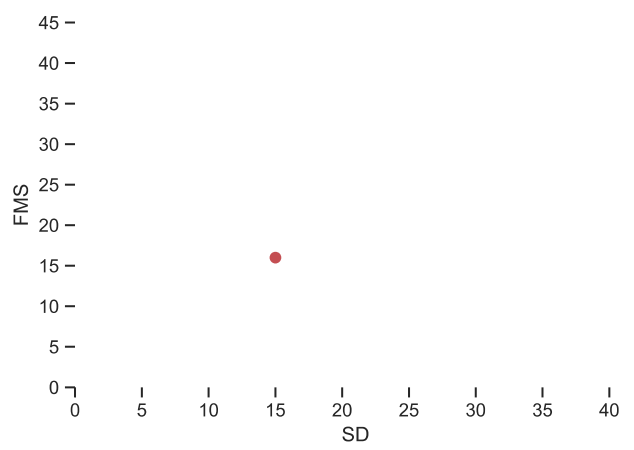

FMS - fine motor skills SD - speech development

Figure 1. Pearson correlation coefficient between the level of speech development and fine motor skills development (September)

According to the diagnostics results, corrective development activities were performed with all the children, especially with the non-verbal 
children and verbal children whose fine motor skills were not sufficiently developed, especially the dynamic and reciprocal skills.

In order to improve the development of fine motor skills different exercises and play methods were used: (playing with small objects, playing with yarn, puzzles, construction sets, counting sticks, activities with paper, activities with pencils, colours and brushes, crayons, finger games in a dry pool).

In order to improve the speech quality, specific exercises were developed for articulation and breathing, exercises for developing of phonological awareness, games and activities for creation and improvement of communication skills, tasks for improving the lexical structure and grammatical constructions.

The diagnostics were repeated in January after finishing the series of sessions of corrective and developmental speech therapy and sessions to improve the fine motor skills of fingers. The methods used were the same as in the beginning of the research. Results showed significant changes in the fine motor skills area where one child obtained 44 points, that is the highest result after the intervention. Six children obtained a high result of 43 points out of 45 available, five children 42 points, four children 41 points, and five children 40 points, six children obtained average results from 26 to 34 points.

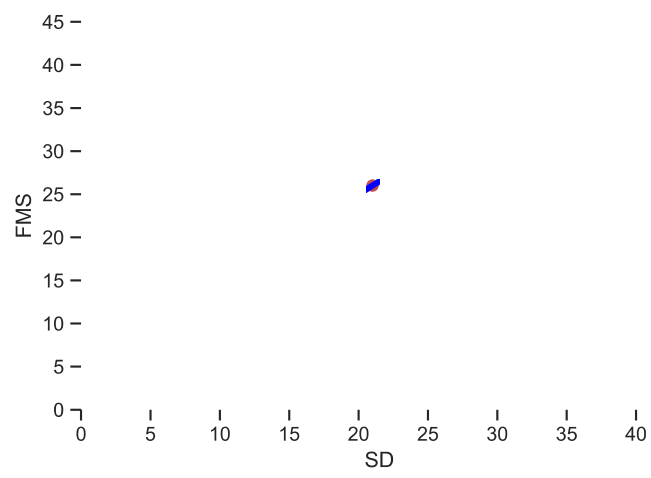

FMS - fine motor skills

$\mathrm{SD}$ - speech development

Figure 2. Pearson correlation coefficient between the level of speech development and fine motor skills development (January)

There are also positive results in the development of speech and language. All children use verbal communication as the main method of communication. Children who were non-verbal in September $(n=5)$, in January, were in the group of children who were poorly verbal, and this 
demonstrates the improvement in their speech abilities. When comparing the development level of language and speech skills and the development of fine motor skills, it can be concluded that in January (see Figure 2) there is a significant correlation between these criteria with a positive coefficient $(r=0.836)$.

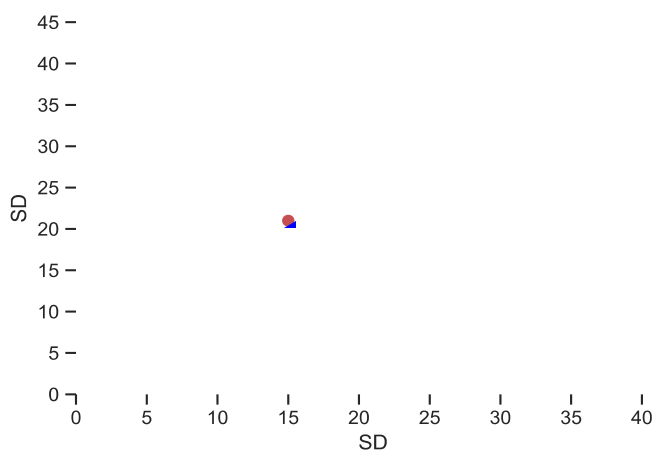

SD - speech development

Figure 3. Pearson correlation coefficient between the level of speech development in September and the level of speech development in January

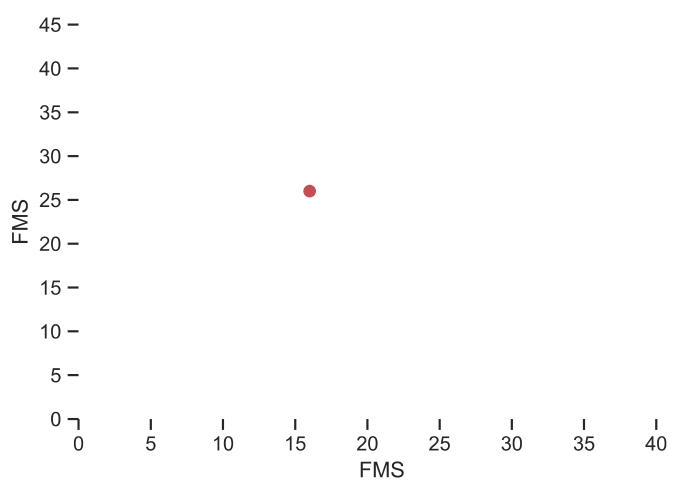

FMS - fine motor skills

Figure 4. Pearson correlation coefficient between fine motor skills development in September and in January

By evaluating the results from September and January it can be concluded that the speech abilities have improved (see Figure 3), the mobility and skills of fingers have improved (see Figure 4), and there is a statistically significant connection and a correlation between the development of speech and fine motor skills. At the end of the research, positive dynamics 
can be observed, and it can be concluded that the improvement of one skill subsequently increases the values of other skills.

\section{Conclusions}

Insufficient development of the fine motor skills influences the speech development of the child: if the level of the fine motor skills development is low then the speech development of the child is also disturbed;

For non-verbal children the level of the fine motor skills development is lower than for verbal children;

The corrective developmental activity sessions for the development of the fine motor skills brought positive results;

The activity sessions for the development of the fine motor skills for non-verbal children with low level of the fine motor skills development showed positive dynamics. The results of the experimental research are provisional, and they need to be tested with a bigger number of children for a longer period of time.

\section{References}

Berninger, V. W., Abbott, R. D., Jones, J., Wolf, B. J., Gould, L., AndersonYoungstrom, M. et al. (2006). Early development of language by hand: Composing, reading, listening, and speaking connections; three letter - writing modes; and fast mapping in spelling. Developmental Neuropsychology, 29(1), 61-92. DOI: http://dx.doi.org/ 10.1207/ s15326942dn2901 5 .

Bindman, S. W., Skibbe, L. E., Hindman A. H., Aram, D., Morrison F. J. (2014). Parental Writing Support and Preschoolers' Early Literacy, Language, and Fine Motor Skills. Early Childhood Research Quarterly, Q4 2014, Vol. 29(4), 614-624. DOI: 10.1016/ j.ecresq.2014.07.002.

Brice, B. (2007). Pirkstinu rotaļas [Finger Games]. Rīga: RaKa.

Brooks, P., Kempe, V. (2014). Encyclopedia of Language Development. United Kingdom: Wiley-Blackwell.

Cameron, C. E., Brock, L. L., Murrah, W. M., Bell, L. H., Worzalla, S. L., Grissmer, D., Morrison, F. J. (2012). Fine Motor Skills and Executive Function Both Contribute to Kindergarten Achievement. Child Development. 2012 Jul-Aug; 83(4): 1229-44. DOI: 10.1111/j.1467-8624.2012.01768.x.

Dinehart, L., \& Manfra, L. (2013). Associations Between Low-Incom Children's Fine Motor Skills in Preschool and Academic Performance in Second Grade. Early edeucation and Development, 2013, Vol. 24 (2), Retrieved from https://primolatvija.hosted. exlibrisgroup.com/primo-explore/fulldisplay?docid $=$ TN_ericEJ1010187\&context.

Kurtz, L. A. (2008). Understanding Motor Skills in Children with Dyspraxia, ADHD, Autism, and Other Learning Disabilities: A Guide to Improving Coordination. Jessica Kingsley Publishers London and Philadelphia. 
Loras, H., Stensdotter, A.-K., Ohberg, F., Sigmundsson, H. (2013). Individual differences in motor timing and its relation to cognitive and fine motor skills. PLoS ONE, Vol. 8(7), p.e.69353. DOI: 10.1371/journal.pone.0069353.

Sibley, B. A., \& Etnier, J. L. (2003). The relationship between physical activity and cognition in children: A meta-analysis. Pediatric Exercise Science, Human Kinestetics Publishers, Inc.

Suggate, S., Stoeger, H., Fischer, U. (2017). Finger-Based Numerical Skills Link Fine Motor Skills to Numerical Development in Preschoolers. Perceptual and Motor Skills, December 2017, Vol. 1249(6), 1085 - 1106. DOI: 10.1177/0031512517727405.

Šternfelde, I. (2017). Sïkās motorikas attistīšana pirmsskolas vecuma bērniem: metodiskais materiāls. [Developing of the fine motor skills in preschool age children: methodological guide] Rīga: Pētergailis.

Tūbele, S., Landra, T., Šūmane, I., Burčaka, M., Laganovska, E., Kušnere, S., Vīgante, R. (2013). Metodiskais materiāls pedagogiem darbam ar izglitojamiem ar jauktiem attistibas traucejjumiem. [The methodological guide for teachers to work with children with mixed developmental disorders] Rīga: VISC.

Turkington, C., Harris, J. (2006). The Encyclopedia of Learning Disabilities. Second Edition. New York: American Bookworks.

Бернштейн, Н. А. (1990). Физиология движений и активность (Fiziologia dvizhenij i aktivnostj) [Movements physiology and activity]. Москва: Наука.

Бернштейн, Н. А. (1991). О ловкости и ее развитии (O lovkosti i jeje razvitii) [Dexterity and its development]. Москва: Физкультура и спорт.

Кольцова, М. М. (1973). Ребенок учится говорить (Rebenok uchitsja govoritj) [The child is studying to speak]. Москва.

Лурия, А. Р. (1973). Основы нейропсихологии (Osnovy nejropsihologii) [The working brain: An introduction of neuropsychology]. Москва: Издательство Московского университета.

Семенович, А. В. (2002). Нейропсихологическая диагностика и коррекция в детском возрасте (Nejropsihologicheskaja diagnostika i korrekcija v detskom vozraste) [Neuropsychology diagnostic and correction in childhood]. Москва: Академия.

Сухомлинский, В. А. (1986). Сто советов учителю (Sto sovetov uchitelju) [100 Pieces of advice for school teacher]. Киев: Радянська школа. 